Full-text Available Online at www.bioline.org.br/ja
J. Appl. Sci. Environ. Manage. June, 2007

Vol. 11 (2) 91 - 93

\title{
Assessment of Possible Impacts of Climate Change in Water Reservoir of Bhopal with Special Reference to Heavy Metals, Central Region - India
}

\author{
${ }^{1}$ CHARU PARASHAR; ${ }^{2}$ SAVITA DIXIT; ${ }^{3}$ RAJNISH SHRIVASTAVA \\ ${ }^{1}$ Department of Civil Engineering, MANIT, Bhopal Email-charu_parashar2001@yahoo.com \\ ${ }^{2}$ Chemistry Department, MANIT, Bhopal Email-savitadixit@yahoo.com \\ ${ }^{3}$ Department of Civil Engineering, MANIT, Bhopal
}

\begin{abstract}
Water is a unique substance. Its liquid face predominates on the Earth. Water of Kolar reservoir was investigated to assess its water quality status. Study reveals that physico - chemical characteristics of the reservoir water largely varied through change of season, degree of anthropogenic activities in and around ,the composition of runoff in the catchment area. Water samples were collected during winter and summer and analysed for various quality parameters with special reference to heavy metals e.g. Iron and Manganese. A perusual of chemical analysis revealed that Iron and Manganese content are more at station $\mathrm{S}_{4}$ which is a channel water outlet of dam. @JASEM
\end{abstract}

Since the inception of mankind air, water and land have nursed and nourished man for his growth and development. During the last century there has been perceptible detoriation in the quality of our environment. Availability of potable water is shrinking in many countries. The water resources of India are unevenly distributed. In many parts of India , women have to trudge long distances to fetch a pitcher of water The catchment of any region acquires importance because it determines the annual water-yield of the river draining it. The physical characteristics of the catchment, viz. the substreams, the land use patterns and the changes therein, the nature and the extent of vegetative cover, the permeability of the soil strata and finally the presence of man made structures for harnessing water in the subcatchments/micro catchments, are the factors which determine the rate of surface water runoff. (Ghosh et al).

Conservation of water and its judicious use are absolutely essential if we do not want to face a water famine in the foreseeable future. The reservoir water is mainly used for drinking irrigation and fishing purposes. The Kolar reservoir is good fish producing water body. Its water is being used for providing irrigation to 33,593 Hectors of land of Sehore District. of Madhya Pradesh. It is a major potable source as it supplies 162 M.L.D. per day to Bhopal .

\section{MATERIALS AND METHODS:}

Water samples were collected from four sampling locations near bank of dam, $500 \mathrm{~m}$ from bank of dam, $1000 \mathrm{~m}$ from bank of dam and channel water outlet $\left(\mathrm{S}_{1}, \mathrm{~S}_{2}, \mathrm{~S}_{3} \& \mathrm{~S}_{4}\right)$ respectively, during winter and summer 2006. The water samples were collected in pre cleaned polypropylene bottles and analyzed according to the procedure prescribed by NEERI (1995) and APHA (1992). High purity certified analytical grade reagents, double distilled de-ionized water and borosil glassware were used through out the study. Sampling sites were selected keeping in mind the feeding source of raw water.

\section{RESULT AND DISCUSSION}

The results obtained in the study on various physical, chemical parameters are shown in Table $-1 \& 2$. The physical chemical data revealed that the temperature varied from $21.5^{\circ} \mathrm{C}$ to $22.5^{\circ} \mathrm{C}$ during winter and $30.0^{\circ} \mathrm{C}$ to $32.8^{\circ} \mathrm{C}$ during summer. The water temperature is one of the most important physical characteristics of ecosystem. It affects a number of water quality parameters that is one of the concern for domestic , environmental, industrial and agricultural applications. The chemical and biological reaction rates increase with increased water temperature. Thus the seasonal variation are quite significant in fresh water lake and ponds and the pattern of variation is dependent on the geographical locations. (Samal, N.R. et. al. IPHE 2004).

$\mathrm{pH}$ has no adverse affect on health. However a lower value below 4 will produce sour taste and above 8.5 an alkaline taste. Higher values of $\mathrm{pH}$ hasten the scale formation in water heating apparatus and also reduce the germicidal potential of chlorine (Dubey N.). $\mathrm{pH}$ was recorded between $7.72 \mathrm{mg} / \mathrm{lit}$. to 8.32 $\mathrm{mg} / \mathrm{lit}$. in winter and $7.87 \mathrm{mg} / \mathrm{lit}$. to $8.58 \mathrm{mg} / \mathrm{lit}$. reflecting slightly alkaline nature. These values were within the permissible limits.

Turbidity was recorded between 3.0 N.T.U. to 4.6 N.T.U. during winter and 2.6 N.T.U. to 6.4 N.T.U. during summer. Water is considered to be of improved quality when it contains turbidity value of 1 NTU or below. Turbidity level exceeding 10 N.T.U. in the drinking water, affects the aesthetic

Email-charu_parashar2001@yahoo.com

Email-savitadixit@yahoo.com 
quality of water significantly. Water may not be safe from hygienic point of view as under such conditions it becomes very difficult to maintain the minimum desirable limit of chlorine in the water.Turbid constituents protects micro organisms against the bactericidal action of chlorine. Abrasive action on pump and pipe lines are caused due to constituents of turbidity.

Hardness is defined as the some of polyvalent cations present in water, notably Calcium and Magnesium. Excess hardness may cause kidney stones, (Jain 1996). High concentration of Calcium in the drinking water is the main cause of hardness. (Joshi and Srivatava 2006). Total Hardness was in the range of $102 \mathrm{mg} / \mathrm{l}$ to $109 \mathrm{mg} / \mathrm{l}$ in winter and $118 \mathrm{mg} / \mathrm{l}$ to 130 $\mathrm{mg} / \mathrm{l}$ in summer.

Alkalinity itself is not harmful to human beings (Trivedy and Goel, 1986). The value of alkalinity provides idea of natural salts present in water (Gawas et. al ). Alkalinity varied in the range of 115 $\mathrm{mg} / \mathrm{l}$ to $118 \mathrm{mg} / \mathrm{l}$ in winter and $132 \mathrm{mg} / \mathrm{l}$ to $140 \mathrm{mg} / \mathrm{l}$ in summer.

The D.O is the one of the vital parameters in water quality assessment. Its presence is essential in aquatic eco system in bringing out various bio chemical changes and its effect on metabolic activities of organism. The D.O. was found in the range of 5.6 $\mathrm{mg} / 1$ to $6.5 \mathrm{mg} / \mathrm{l}$ in winter and $5.5 \mathrm{mg} / \mathrm{l}$ to $6.5 \mathrm{mg} / \mathrm{l}$ in summer.
In the present study value of chloride was recorded between $7.0 \mathrm{mg} / \mathrm{l}$ in winter and $8.0 \mathrm{mg} / \mathrm{l}$ in summer. Required desirable limit of chloride suggested by BIS is $250 \mathrm{mg} / \mathrm{l}$. Beyond this limit taste, corrosion and palatability of water is affected. Beside imparting salty taste water high level of chloride have deleterious effects on metallic pipes and structure as well as on agricultural plants are also reported (Narendra Kumar G. 2003).

Sulphate ranged between $2.4 \mathrm{mg} / 1$ to $3.9 \mathrm{mg} / \mathrm{l}$ in winter and $3.2 \mathrm{mg} / \mathrm{l}$ to $4.8 \mathrm{mg} / \mathrm{l}$ in summer.

Heavy metal are harmful and insidious pollutants because of their non bio degradable nature and their potential to cause adverse effects in human beings beyond certain level of exposure and absorption. Heavy metal can cause bio- chemical effects such as inhibition of enzymes, genetic damage and hypertension( Nayak and Sawant 1996 Zemanky 1974).

In the present study Iron was $0.05 \mathrm{mg} / \mathrm{l}$ in winter and $0.02 \mathrm{mg} / 1$ to $0.07 \mathrm{mg} / \mathrm{l}$ in summer. Consumption of drinking water with high concentration of iron can lead to liver disease over a long period of time (Shri Hari and Raghvendra 2003, M. Joshi and Srivastava 2006).

Mangnese was in the range $0.06 \mathrm{mg} / 1$ to $0.40 \mathrm{mg} / \mathrm{l}$ in winter and $0.24 \mathrm{mg} / 1$ to $0.47 \mathrm{mg} / \mathrm{l}$ in summer Mangnese enter in drinking water system from natural geological sources.

Table 1. KOLAR RESERVOIR (winter)

\begin{tabular}{|c|c|c|c|c|c|c|c|c|c|c|}
\hline Stations & $\begin{array}{r}\text { Temp } \\
\left({ }^{\circ} \mathrm{C}\right)\end{array}$ & $\begin{array}{c}\text { TB } \\
\text { N.T.U }\end{array}$ & TA & $\mathrm{TH}$ & $\begin{array}{c}\mathrm{Cl}^{-} \\
\mathrm{mg} / \mathrm{L}\end{array}$ & $\begin{array}{l}\mathrm{SO}_{4}{ }^{2-} \\
\mathrm{mg} / \mathrm{L}\end{array}$ & $\begin{array}{c}\mathrm{Fe} \\
\mathrm{mg} / \mathrm{L}\end{array}$ & $\begin{array}{l}\mathrm{Mn}^{2+} \mathrm{m} \\
\mathrm{g} / \mathrm{L}\end{array}$ & $\mathrm{pH}$ & $\begin{array}{c}\mathrm{D} \mathrm{O} \\
\mathrm{mg} / \mathrm{L}\end{array}$ \\
\hline $\begin{array}{l}\text { Near Bank of Kolar } \\
\text { dam }\left(S_{1)}\right.\end{array}$ & 22.0 & 4.2 & 115 & 102 & 7 & 2.5 & Nil & 0.06 & 8.30 & 6.5 \\
\hline $\begin{array}{l}500 \mathrm{~m} \text { away from } \\
\text { bank of Kolar Dam } \\
\left(\mathrm{S}_{2}\right)\end{array}$ & 21.5 & 4.0 & 115 & 102 & 7 & 2.6 & Nil & 0.05 & 8.30 & 6.6 \\
\hline $\begin{array}{l}1000 \mathrm{~m} \text { away from } \\
\text { bank of Kolar dam } \\
\left(\mathrm{S}_{3}\right)\end{array}$ & 22.0 & 4.6 & 116 & 102 & 7 & 2.4 & Nil & 0.07 & 8.32 & 6.5 \\
\hline $\begin{array}{l}\text { Channel water } \\
\text { outlet of dam }\left(\mathrm{S}_{4}\right)\end{array}$ & 22.5 & 3.0 & 118 & 109 & 7 & 3.9 & 0.40 & 0.040 & 7.72 & 5.6 \\
\hline
\end{tabular}

Conclusion: Perusal of chemical analyses revealed that in present study all the physico-chemical parameters such as $\mathrm{pH}$, Turbidity, total hardness, DO, chloride sulphate, iron and manganese were within the permissible standard of drinking water as prescribed in BIS -10500. Seasonal variations are clear in physico-chemical parameters as shown in Table 1 and 2. pH, DO of samples taken at station $\mathrm{S}_{4}$ is less than the other stations. This may be as the water is coming from bottom layer of the reservoir to the channel water outlet of dam $\left(\mathrm{S}_{4}\right)$. $\mathrm{pH}$ and D.O. in water from bottom sample is lower than the surface water. The pattern of water quality of samples collected from the dam was different than those collected from front portion of intake channel. It appears its due to flow of water through sluice gate, while the water in the reservoir was almost stationery and hence the quality of water was unaltered. The 
study clearly shows that the built of manganese concentration is due to putrification of vegetation which was maximum in front of sluice gate due to flow of water. The flow of water causes consequent flow of putrified vegetation towards the sluice gate. Hence water of Kolar reservoir is of the safe potable source for the residents of Bhopal.

Table 2. KOLAR RESERVOIR (summer)

\begin{tabular}{|c|c|c|c|c|c|c|c|c|c|c|}
\hline Stations & $\begin{array}{l}\text { Temp ( } \\
\left.{ }^{\circ} \mathrm{C}\right)\end{array}$ & TB N.T.U & TA & $\mathrm{TH}$ & $\begin{array}{c}\mathrm{Cl}^{-} \\
\mathrm{mg} / \mathrm{L}\end{array}$ & $\begin{array}{l}\mathrm{SO}_{4}^{2-} \\
\mathrm{mg} / \mathrm{L}\end{array}$ & $\begin{array}{c}\mathrm{Fe} \\
\mathrm{mg} / \mathrm{L}\end{array}$ & $\underset{\mathrm{g} / \mathrm{L}}{\mathrm{Mn}^{2+} \mathrm{m}}$ & $\mathrm{pH}$ & $\begin{array}{r}\mathrm{D} \mathrm{O} \\
\mathrm{mg} / \mathrm{L}\end{array}$ \\
\hline $\begin{array}{l}\text { Near Bank of Kolar } \\
\text { dam }\left(S_{1}\right)\end{array}$ & 32.5 & 3.6 & 132 & 120 & 8 & 3.5 & 0.02 & 0.32 & 8.4 & 6.2 \\
\hline $\begin{array}{l}500 \mathrm{~m} \text { away from } \\
\text { bank of Kolar Dam } \\
\left(\mathrm{S}_{2}\right)\end{array}$ & 32.8 & 2.7 & 132 & 120 & 8 & 3.6 & 0.02 & 0.25 & 8.5 & 6.5 \\
\hline $\begin{array}{l}1000 \mathrm{~m} \text { away from } \\
\text { bank of Kolar dam } \\
\left(\mathrm{S}_{3}\right)\end{array}$ & 32.8 & 2.6 & 135 & 118 & 8 & 3.2 & 0.02 & 0.24 & 8.6 & 6.5 \\
\hline $\begin{array}{l}\text { Channel water outlet } \\
\text { of dam } \mathrm{S}_{4} \text { ) }\end{array}$ & 30.0 & 6.4 & 140 & 130 & 8 & 4.8 & 0.07 & 0.47 & 7.9 & 5.5 \\
\hline
\end{tabular}

$T B=$ Turbidity, $T A=$ total alkalinity, $T H=$ total hardness

\section{REFERENCES}

American Public Health Association, (1995), Apha . Standard methods for the examination of water and waste water. $19^{\text {th }}$ Ed. American Public Health Organisation, Americal Water Works Association.Water Pollution Control Federation, Washington, D.C.

Dubey Neelam ,Comparative status of Quality drinking Water of Bhopal city Filteration Plants and Ground Water with special reference to Heavy Metals, Organo Chemicals Ph.D. Theses,, Barkatullah Univerity Bhopal.

Gawas, A.D.,. Lokhande , P.B. and Mujawar, H.A., (2006), Study of physico-chemical parameters of surface waters in the Mahad Industrial Area, Poll. Res. 25(1), 109-114.

Ghosh,T.K., Merchant, B, Shakila and Kaul, S.N. Protection of Ecological Sensitive Areas: Origin of Rivers and Upper Catchment Areas. Journal of IAEM, Vol.31,59-64 (2004).
Joshi, M. and Srivatava, R.K. (2006), Study of Drinking Water Quality in Tarai Region Uttranchal. Poll. Res. 25 (1); 179-183.

Joshi M. and Srivastava R.K. (2006), Removal of Iron from Waste Water by using Non Conventional eco-friendly material. Pollution Research 25(1) p. 185 - 188.

Narendra Kumar, G. et.al. (2003). Impact of Development of Water Quality of Pondichery Region. ournalof IPPH. Vol.3-p 53-57.

Nayak, M.S. and Sawant, A.D.(1996), Heavy Metal Content in Drinking Water of Mumbai City . Indian J. Environ. HLTH. Vol. 38 No. 4. p 246 to 245 .

Neeri (1991) Manual of water and pollution control (Vol.1).

Samal N.R. et.al.(2004) Seasonal Response of Water Temperature of Rabindra Sarobar, The National Lake in a Relation to $\mathrm{pH}, \mathrm{DO}, \mathrm{BOD}$ and COD, Journal of IPHE, Vol. No.2.

Shrihari, S. and Raghvendra, S.K. (2003), Assortments dissolved Iron on laterite soil. Pollution Research 22(4) 507-510. 